\title{
The International and Domestic Determinants of Insider Trading Laws
}

\author{
ANDREW Kerner \\ University of Michigan \\ AND \\ JEFFREY KUCIK \\ Emory University
}

\begin{abstract}
Why do some countries protect minority shareholders from rent-seeking by corporate insiders while others do not? To the extent that there has been convergence toward shareholder-friendly laws, what factors have shaped that convergence? We explore this question by examining the worldwide diffusion of insider trading laws through a series of event history analyses. We argue that variation in the adoption and enforcement in insider trading laws can be best explained by the interaction of rising international competitive pressures to attract investment capital through investor-friendly laws and electoral laws that make governments more or less vulnerable to economic voting. We find that governments are more likely to adopt and enforce insider trading laws when they face reelection under electoral laws that make them relatively vulnerable to economic voting and when they face international competitive pressures. Moreover, we find that the impact of domestic political institutions declines in significance as international competitive pressures increase, and vice-versa.
\end{abstract}

States vary widely in the extent to which they protect minority shareholders from rent-seeking by corporate insiders-that is, managers, directors, and controlling shareholders. To illustrate this variation, Figure 1 shows the 2009 rankings of investor protection among high-income democracies as complied and reported by the Doing Business project of the World Bank. ${ }^{1}$ These ratings were compiled for 178 countries at various development levels. As can be seen, there is considerable variation, even among high-income democracies. Some countriesNetherlands, Austria, Greece, and Switzerland-not only lag behind other high-income democracies, they are among the lowest in the world. This variation is puzzling given the general consensus among economists and policymakers that protecting investor rights contributes positively to financial market development by, for example, encouraging higher share prices, greater capital market liquidity, larger initial public offerings, and more entry by new firms. ${ }^{2}$ Economists have

\footnotetext{
1 The Investor Protection Index is composed of three subindices: mandatory disclosure of related party transactions, the extent of legal liability for company directors, and the legal standing of shareholders in the event of a violation. Available at http://www.doingbusiness.org.

${ }^{2}$ For several prominent examples see La Porta et al. (1997), La Porta, Lopez-de-Silanes, Shleifer, and Vishny (1997, 1998, 2000), Rajan and Zingales (2003), Castro, Luca Clementi, and MacDonald (2004), Tiberghein (2007), Bebchuk and Neeman (forthcoming), Perotti and Volpin (2004, 2007) and Beny (2008).
} 


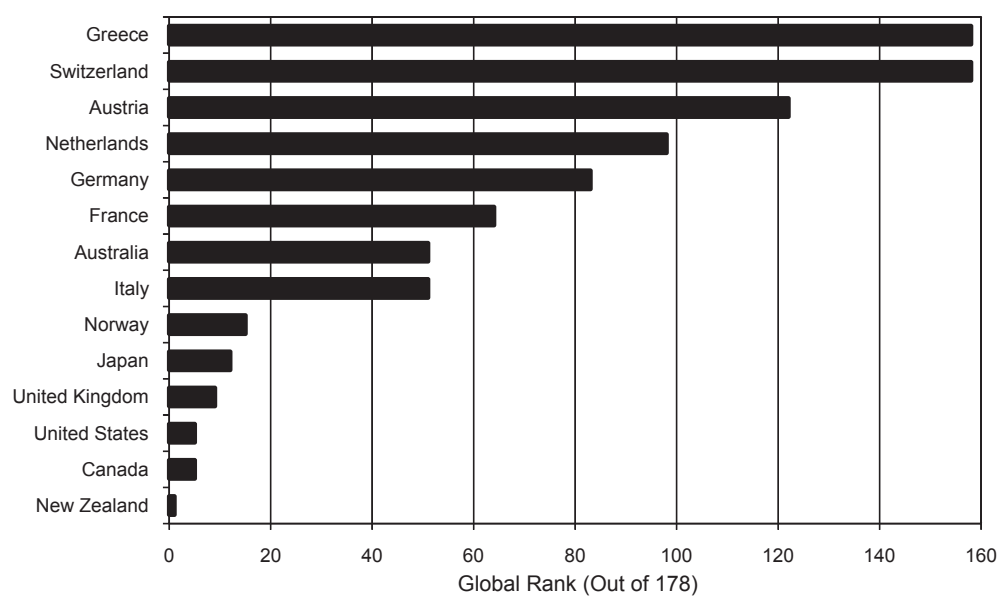

Fig 1. World Ranking of Investor Protection

further argued that the financial development engendered by investor protections is an important source of national comparative advantage and long-term economic growth. ${ }^{3}$ In light of all these benefits, what explains cross-national variation in the provision of investor protections?

Extant answers to this question focus primarily on political competition between domestic interest groups. Interest group theories begin with observation that the benefits accrued from investor protections come at the expense of corporate insiders, whose rent-seeking opportunities are constrained by the adoption and enforcement of these laws. Preferences diverge as a result; insiders typically oppose high levels of investor protection while outsiders investors support it. Interest group theories have looked to domestic political institutions, and electoral rules in particular, to explain how these competing preferences are translated into policy. ${ }^{4}$

A great deal of empirical evidence has shown that domestic political institutions influence politicians' incentives to adopt and enforce investor protections. However, this literature's focus on largely time-invariant institutions means that these theories cannot account for the significant variation within states over time (Rajan and Zingales 2003). Insider trading laws are just one example of a policy that exhibits considerable variation over time. Of the 51 states with active stock markets in 1965, only the United States banned insider trading. By 1999, this number had grown to 87 out of 103 stock markets. Domestic institutions alone cannot explain this trend. We believe that the key component missing from these theories is sufficient account of the role played by international competitive pressures and, in particular, how these pressures interact with domestic institutions.

Recent literature on mechanisms of global policy diffusion has shown that competition over capital can help explain the proliferation of liberal market policies (Simmons and Elkins 2004; Elkins, Guzman, and Simmons 2006). We draw upon these findings to argue that competition over internationally mobile capital-portfolio investment from either domestic or foreign sources-creates material incentives for governments to adopt investor protections. ${ }^{5}$ In related

\footnotetext{
${ }^{3}$ See Becker and Greenberg (2003), Demirgüç-Kunt and Maksimovic (1998), King and Levine (1993), Beck, Levine, and Loayza (2000) and Svaleryd and Vlachos (2005).

${ }^{4}$ Among the works making this argument are Bebchuk and Neeman (forthcoming), Roe (2003), Gourevitch and Shinn (2005), La Porta, et al. (1997), Pagano and Volpin (2005), Perotti and Volpin (2007).

${ }^{5}$ Note that we do not consider foreign direct investors in this analysis, who may benefit from rent-seeking opportunities stemming from their controlling share in the firm they invest in.
} 
work, Basinger and Hallerberg (2004), Brooks (2005, 2007) and others that have noted the mediating effect domestic institutions have on competitive diffusion processes. We therefore expect competitive pressures and domestic political institutions to condition one another. To motivate our hypotheses, we start with the observation that a government's tenure security is closely tied to economic performance and that governments that adopt suboptimal policies are more likely to face public sanction (Hibbs 2000). Because the preferences of corporate insiders diverge from those of minority shareholders and the general public-'outsiders" - the decision of whether to ban insider trading reflects a trade-off between competing interests. In practice, politicians balance the financial contributions made by corporate insiders and the votes that accrue, directly or indirectly, from market performance.

Accordingly, we argue that the incentives to protect investor rights increase in the public accountability of politicians. Accountability is highest under two conditions: (i) when investor protections have a large impact on economic performance and, thus, on votes; and (ii) when votes have a relatively large impact on the likelihood of politicians retaining office relative to financial contributions. On the first point we see a clear role for international competitive pressures. Policy decisions relating to investor protection affect states' abilities to attract internationally mobile portfolio capital. Countries that permit rent-seeking find it more difficult to attract capital from risk-averse investors, particularly when there are comparable markets where investors can avoid rent-seeking. The adverse welfare consequences of losing investment capital include erosion of the tax base, the accumulation of external debt, depressed share prices and, most importantly for voters, reductions in personal income (Alesina and Tabellini 1988; Collier, Hoeffler, and Pattillo 2001). All of these undesirable effects place pressure on governments to adopt and enforce investor protections. On the second point we follow Rogowski and Kayser's (2002) finding that marginal shifts in vote share have a greater impact on the likelihood of retaining office when governments face reelection under majoritarian, rather than proportional, electoral rules.

We test our hypotheses through a series of event-history analyses that focus on the adoption and initial enforcement of insider trading laws. Analyzing both outcomes gives us confidence that we are measuring meaningful policy changes, not just inconsequential changes to laws on the books, particularly in light of empirical evidence that enforcement, rather than adoption, eases investor fears over rent-seeking (Bhattacharya and Daouk 2002; Bushman, Piotroski, and Smith 2005). Consistent with our expectations, we find that governments are more likely to adopt and enforce insider trading laws under majoritarian electoral rules, but that this relationship is attenuated as competitive pressures increase. We also find that competitive pressures increase the likelihood that a country adopts and enforces an insider trading law but that this relationship is attenuated in countries with majoritarian electoral rules, in which even modest pressure will be sufficient to cause governments to ban insider trading.

This article makes three important contributions. First, by incorporating international competition into our theory of investor protection, we provide a framework that is more encompassing and better fits the data than do extant models that focus overwhelmingly, if not solely, on domestic politics. Second, our study of insider trading laws allows us to observe the precise political-economic conditions in place at the time of policy change over a span of nearly 50 years, over which time we can observe nearly the full universe of insider trading law adoption and initial enforcement events. This stands in sharp contrast to-and, we think, is a considerable improvement on-extant statistical work on investor protections that relies on either cross-sectional data, or relatively short time-series with very little variation over time. Third, this paper 
contributes to the broader literature on policy diffusion. We find that competitive pressures, particularly those that come from the policy decisions in countries with similar levels of development, are a key source of policy pressure. Moreover, we find that the competitive diffusion process that has defined the spread of insider trading laws cannot be meaningfully interpreted without reference to domestic politics.

\section{Literature Review}

Interest group theories are currently the dominant perspective on investor protection. ${ }^{6}$ This literature focuses on competition between domestic interests-typically: corporate insiders, labor, and minority shareholders-for whom the provision of investor protections has significant distributional implications. Preferences over policy are assumed to diverge among these groups. Investor protections are opposed by insiders and, typically, labor. Insiders oppose protections because they reduce insiders' rent-seeking opportunities-for example, unduly high executive compensation plans, asset-stripping, insider trading, etc.-and because they expose incumbent firms to increased competition from entrepreneurs with easier access to investment capital (Rajan and Zingales 2003; Perotti and Volpin 2007). Labor is typically thought to oppose investor protection because a greater emphasis on shareholder value can place downward pressure on the wage bill, either through pay cuts or layoffs (Pagano and Volpin 2001, 2005; Roe 2003). The strongest support for investor protections comes from minority shareholders, who benefit from resulting increases in the value of their holdings (Pagano and Volpin 2005; Perotti and von Thadden 2006). Roe (2003), and Gourevitch and Shinn (2005), in their characterizations of the "corporatist coalition", argue that consensual politics is the key factor allowing labor and insiders to form a successful political coalition against investor protection. ${ }^{7}$

In addition, some interest group theories incorporate the public interest in promoting financial development (and therefore in growth and a consumer surplus) through high levels of investor protection. Perotti and Volpin (2004, 2007) and Bebchuk and Neeman (forthcoming) both show that public preferences that are motivated by changes in welfare deriving from stock market performance can influence policy decisions. These papers suggest that more publicly accountable governments feel greater pressure to cater to the public interest, as opposed to appeasing corporate insiders, and will therefore adopt more shareholder-friendly corporate governance regimes. ${ }^{8}$ In a related work on the regulation of firm entry, Scartascini (2002) argues that the relative vulnerability of governments elected under majoritarian electoral laws leads these governments to provide the public good of low barriers to entry.

\footnotetext{
${ }^{6}$ The prominent exception is the law and finance theory offered by La Porta et al. (1998). However, this work has been heavily criticized, (see Schmidbauer 2006 for an overview of the debate).

7 There is, however, a considerable amount of controversy over labor's preferences as well the extent to which they are involved in the modern policy-making process (for example, Cioffi and Hopner 2006; Culpepper forthcoming-a,b). Many elements of investor protection, such as transparency in accounting or bans on insider trading, do not meaningfully impact corporate control or employment security in the way that (for example) takeover rules do. Thus, on some issues central to the protection of minority shareholders, there are fewer material incentives for labor to mobilize in opposition to investor protections. Similarly, Gourevitch and Shinn (2005) argue that pension holding by labor may align their interests with minority shareholders and in favor of increased investor protections.

${ }^{8}$ These theories assume, as we do, that the balance of special interest lobbying will fall on the side of insider interests, who typically face far smaller barriers to collective action than do shareholders. In the special case in which special interests are aligned with the public interests, the policy choice becomes trivial.
} 


\section{International Politics of Investor Protection}

However, there are strong reasons to suspect that existing interest group theories are incomplete. First, domestic political institutions-including electoral systems-are rarely altered and therefore cannot explain the considerable changes in the protection of investors within states over time. Second, the interest group literature has not yet offered an account of how international market forces bear on the decisions to adopt investor-friendly policies. This is an important omission and it is the principal area in which we seek to contribute. Domestic politics do not occur in a vacuum. Governments' abilities to maintain competitive capital markets are tied closely to other states' policy decisions. It is therefore unsurprising that models of diffusion have recently become a mainstay of the international political economy literature (Simmons and Elkins 2004 and Elkins et al. 2006).

Recently, international competition has also been recognized as a force for policy homogenization in investor protection and corporate ownership structures. Hansmann and Kraakman (2001) and Rajan and Zingales (2003) both note that exposure to the global economy can lead governments to adopt proshareholder policies. Kamar (2006) notes that many recent pro-investor reforms across Europe have been motivated by politicians' desires to remain competitive with neighboring markets in their drive to attract equity capital. Hebb and Wójcik (2005) note that the reallocation of investment capital from states with poor corporate governance standards to states with higher corporate governance standards can motivate significant reforms in the developing world. In spite of these examples, which provide a firm foundation for investigating the role of competitive pressures, diffusion and its interaction with domestic political institutions have remained largely absent in statistical work on investor protections.

\section{Theory}

To motivate our hypotheses and empirical tests we develop a simple model of investor protection. We take as given the perception among policymakers that protecting investors will help develop stock markets and thereby aid economic growth. ${ }^{9}$ In our model, governments choose between providing a public good (high levels of investor protection) and a private good (low level of investor protection). Our model is similar in this regard to those presented by Grossman and Helpman (2001), Rogowski and Kayser (2002) and Scartascini (2002). We model the decision over investor protection as a game of complete information involving two actors: an incumbent government and a lobby group representing corporate insiders (Figure 2 shows the sequence of play). ${ }^{10}$ In our model, governments are responsible for setting the level of investor protection, which we denote as $X \in[0,1]$, with higher values indicating higher levels of protection. Governments' decision over $X$ is influenced by the lobbying efforts of insiders

\footnotetext{
${ }^{9}$ The prevalence of this perception is well captured by the Reports on the Observance of Standards and Codes (ROSC) a joint project between the IMF and World Bank, in cooperation with the OECD, IOSCO, and others that rates corporate governance standards in emerging economies with the express purpose of encouraging crossnational harmonization in regulatory practices including corporate governance standards. However, we should note that this perception does not accurately describe conventional wisdom about all corporate governance issues at all times. The Anglo-American model has not always dominated and some of its provisions-liberal takeover laws, for example-remain controversial in many countries. Nonetheless, we think this assumption accurately captures the debate over insider trading laws. While dissension exists in the literature (for example, Manne 1966) we are unaware of parallel dissensions in the public policy sphere. As noted above, this is surely informed by the fact that insider trading laws (unlike takeover laws) do not disrupt ownership patterns or employment security.

${ }^{10}$ Some readers may note that our model does not feature international organizations such as the World Bank, IMF, OECD, and others that been active in the promotion of high corporate governance standards, including insider trading laws. Much of this activity has been a response to the Asian financial crisis of 1997, and thus does not bear strongly on our sample, which ends in 1999 due to data restrictions.
} 


\begin{tabular}{|c|c|c|c|}
\hline $\mathrm{T}=1$ & $\mathrm{~T}=2$ & $\mathrm{~T}=3$ & $\mathrm{~T}=4$ \\
\hline $\begin{array}{l}\text { Insiders Announce } \\
\text { Contribution } \\
\text { Schedules }\end{array}$ & $\begin{array}{l}\text { Government Chooses } \\
\text { Policy and Collects } \\
\text { Contributions }\end{array}$ & $\begin{array}{l}\text { Economic Effects } \\
\text { Are Realized }\end{array}$ & Election \\
\hline
\end{tabular}

FIG 2. Sequence of Moves

and politicians' desire to be reelected. The game begins with insider lobbyists declaring a "contribution schedule"- a complete menu noting the size of the gift they are willing to give in exchange for any possible policy choice made by the government, which in this case refers to any value of $X$. We denote this gift as $C(X)$. Following from similar models in the literature, corporate insiders adopt a "truthful" contribution schedule in which policies closer to their ideal point are rewarded with larger contributions. ${ }^{11}$

In the second move of the game, the government chooses a policy $X$ and then collects $C_{\mathrm{I}}(X)$ from the insider lobbyists. The chosen policy then directly affects subsequent market performance. Ceteris paribus, if investor rights are protected markets perform well; if not, then markets perform poorly. This is obviously an abstraction from the reality of very noisy markets that respond to a variety of stimuli, but it is an abstraction that nonetheless well captures recent empirical work in economics and the general consensus among policymakers. In the final move of the game, voters cast their ballots in accordance with perceived changes in their individual welfares. Voters need not observe the policy directly to punish incumbent for perceived welfare loses. Thus, governments that do not protect investor rights are more likely to face public sanction, regardless of the visibility of the policy to voters. ${ }^{12}$ The core tension faced by politicians is therefore how to balance the interests of money-contributing insiders against their own electoral interest in the votes of the general public.

\section{Model}

To structure the utility functions we assume that both actors have an ideal level of investor protection- $X^{\mathrm{P}}$ for government and $X^{\mathrm{P}}$ for insiders-that is the product of their own local knowledge of investor protection's likely impact on overall market growth and the size of insider's rents, respectively. We assume that $X^{P}$ is the policy that maximizes economic performance and, therefore, reelection. ${ }^{13}$ We assume that $X^{I}$ is less than or equal to $X^{\mathrm{P}}$, as insiders have no incentive to lobby for a policy that is gives shareholders an inefficiently large amount of power. The utility functions for politicians and insiders are stated as quadratic loss functions and are given below.

$$
\begin{gathered}
\text { Politician's utility function }=G\left(X, C_{\mathrm{I}}(X)\right)=-W_{\mathrm{p}} * \frac{\left(X-X^{\mathrm{P}}\right)^{2}}{2}+C_{\mathrm{I}}(X) \\
\text { Insider's utility function }=U\left(X, C_{\mathrm{I}}(X)\right)=-W_{\mathrm{I}} * \frac{\left(X-X^{\mathrm{I}}\right)^{2}}{2}-C_{\mathrm{I}}(X)
\end{gathered}
$$

\footnotetext{
${ }^{11}$ See, for example, Bernheim and Whinston (1986), Grossman and Helpman (1994, 1996), and Dixit, Grossman, and Helpman (1997) for a fuller justification of our use of "truthful" contribution schedules.

${ }^{12}$ Investment decisions can have politically sensitive implications aside from welfare gains. For example, foreign ownership of strategically important industries such as ports can generate political controversy-for example, Dubai Ports World's attempted purchase of P\&O. However, because these purchases involve a controlling share there is no reason to expect that they would be more likely to occur in the presence of an insider trading law.

${ }^{13}$ Note that $X^{\mathrm{P}}$ is the government's ideal policy in the absence of lobbying. The manner in which government trades off between votes from the public and lobbying from insiders is captured in the equilibrium policy, $\dot{X}$.
} 
We define $W_{\mathrm{p}}$ as the relative weight governments place on economic outcomes, which in our model equates to the effect those outcomes have on reelection bids, vis-à-vis political contributions. The weight governments give to gifts from lobbyists is normalized to 1. In keeping with Bebchuk and Neeman (forthcoming) and Perotti and Volpin (2004, 2007), we assume that gifts from lobbyists have additional utility that is unconnected to an incumbent government's ability to hold office. ${ }^{14} W_{\mathrm{I}}$ is the weight that insiders assign to policy vis-à-vis gift giving. The weight that insiders assign to the costs of gift giving is normalized to one.

The equilibrium solution to this game reduces to one of direct lobby control wherein lobbies simply compensate politicians with money for the utility lost by deviating from $X^{\mathrm{p}}$. To be more specific, the lobbyist solves the following maximization problem:

$$
\begin{gathered}
\max (X, C(X))-W_{\mathrm{I}} * \frac{\left(X-X^{\mathrm{I}}\right)^{2}}{2}-C_{\mathrm{I}}(X) \\
\text { s.t. }-W_{\mathrm{p}} * \frac{\left(X-X^{\mathrm{p}}\right)^{2}}{2}+C_{\mathrm{I}}(X)=-W_{\mathrm{p}} * \frac{\left(X^{\mathrm{p}}-X^{\mathrm{p}}\right)^{2}}{2}=0
\end{gathered}
$$

Equation (4) shows that the lobby sets their contribution so that the government is left indifferent between adopting their ideal point and the equilibrium policy. This implies that $C_{\mathrm{I}}(X)$ is set as

$$
W_{\mathrm{p}} * \frac{\left(X-X^{\mathrm{p}}\right)^{2}}{2}
$$

so that the lobbyist is maximizing:

$$
\max (X)-W_{\mathrm{I}} * \frac{\left(X-X^{\mathrm{I}}\right)^{2}}{2}-W_{\mathrm{p}} * \frac{\left(X^{\mathrm{p}}-X^{\mathrm{p}}\right)^{2}}{2}
$$

which yields:

$$
W_{\mathrm{I}}\left(X^{\mathrm{I}}-\dot{X}\right)+W_{\mathrm{p}}\left(X^{\mathrm{p}}-\dot{X}\right)
$$

Where $\dot{X}$ indicates the equilibrium level of $X$. From the first order conditions the equilibrium policy choice is

$$
\dot{X}=\frac{\left(X^{\mathrm{I}} W_{\mathrm{I}}+W_{\mathrm{p}} X^{\mathrm{p}}\right)}{W_{\mathrm{p}}+W_{\mathrm{I}}}
$$

As Dixit et al. (1997) note, Equation (7) is effectively a weighted average of each actor's policy preferences. The intuition behind Equation (7) is straightforward: as $W_{\mathrm{p}}$ increases $\dot{X}$ approaches $X^{\mathrm{p}}$, and when $W_{\mathrm{I}}$ increases, $\dot{X}$ approaches $X^{\mathrm{I}}$. Because $X^{\mathrm{P}} \geq X^{\mathrm{I}}$ by definition, $\dot{X}$ is therefore increases in $W_{\mathrm{p}}$.

Because insider lobbyists will choose a contribution schedule that keeps politicians indifferent between accepting insiders' preferred policy and their own, we can find the equilibrium contribution $\dot{C}_{\mathrm{I}}(X)$ by plugging Equation (7) into Equation (1) and setting this equation to 0 . This yields,

\footnotetext{
14 This assumption has support in the empirical literature. Extant empirical literature consistently finds that campaign spending by the incumbent lacks a meaningful impact on votes (for example, Glantz, Abramowitz and Burkhart 1976; Jacobson 1978, 1980, 1985, 1990; Welch 1981; Abramowitz 1991; Levitt 1994; Gerber 2004; and see Green and Krasno 1988 for an alternative finding). In practice, one could easily allow reelection odds to be increasing in campaign contributions. As long as contributions have some positive utility outside of reelection, and as long as incumbent governments' reelection prospects are more closely tied to economic outcomes during their tenure than to campaign spending, the results of this model would remain unchanged. However, the cost to parsimony for allowing reelection odds to increase in campaign contributions is significant. Analysis of such dynamics, while interesting in their own right, falls outside the purview of this paper.
} 


$$
\dot{C}_{\mathrm{I}}(\dot{X})=W_{\mathrm{p}} *\left(\frac{\left(X^{\mathrm{I}} W_{\mathrm{I}}+W_{\mathrm{p}} X^{\mathrm{p}}\right)}{\frac{\left(W_{\mathrm{p}}+W_{\mathrm{I}}\right)}{2}}-X^{\mathrm{p}}\right)^{2}
$$

\section{Hypotheses}

While this model suggests a variety of hypotheses, we focus on one implication in particular: levels of investor protection increase in government accountability-that is, when $W_{\mathrm{p}}$ assumes high values. We argue that $W_{\mathrm{p}}$ derives from both domestic and international sources. On the domestic side, accountability varies as a function of political institutions. Electoral rules dictate how politicians make tradeoffs between competing interests. Rogowski and Kayser (2002) argue that electoral rules determine the relative weights that politicians place on votes (outsiders' interests) and financial contributions (insiders' interests). They attribute these differences to seat-vote elasticity-the effect of incremental changes in vote share on legislative seat shares. Seat-vote elasticity is comparatively higher in majoritarian systems than in proportional representation systems. This disparity in elasticity across institutional structures has important implications for policy: it implies that reelection prospects are tied more closely to votes than financial contributions under majoritarian rules. Policy decisions reflect this imbalance. Rogowski and Kayser show majoritarian systems produce outcomes that favor the interests of consumers over those of producers. In our context, their theory predicts that majoritarian states are more likely to adopt and enforce investor protections than their proportional representation counterparts. This leads to our first hypothesis.

Hypothesis 1: Governments are more likely to adopt and enforce insider trading laws under majoritarian electoral rules.

Domestic institutions do not tell the whole story. Rogowski and Kayser's (2002) logic only applies if investor protections have an effect on votes. If investor protections do not affect the welfare of voters then they have no incentives to sanction governments by voting them out of office, and governments therefore risk nothing by favoring insiders' interests by permitting rent-seeking. The question therefore remains: Under what conditions do investor protections affect the welfare of the voting public? To answer this question we look to the important role played by international competitive pressures.

We argue that competition over internationally mobile portfolio capital creates material incentives for states to adopt and enforce investor protections. States can pay a high cost for allowing rent-seeking. Failing to protect investor rights reduces the accumulation of internationally mobile capital. Studies have shown that international investors' portfolios tilt toward markets with high levels of investor protections (for example, Aggarwal, Klapper, and Wysocki 2005) and that portfolio investors will occasionally pull their money out of a market that permits rent-seeking (Hebb and Wójcik 2005). Capital flight has a number of adverse effects on welfare. An efficient and well-capitalized financial system helps channel savings into productive use by domestic industry (King and Levine 1993). Conversely, shortages of capital reduce the domestic tax base, generate incentives for governments to accumulate external debt and place downward pressure on personal income levels (Alesina and Tabellini 1988; Lensink, Hermes, and Murinde 2000; Collier et al. 2001). In aggregate, these adverse effects can create widespread dissatisfaction with the economic performance of incumbent governments. The willingness of investors to abandon markets, along with 
these concomitant welfare losses, places pressure on politicians to compete for internationally mobile capital.

These pressures are not evenly distributed across space or time. One of the principal sources of competition for capital is between states at similar levels of development. ${ }^{15}$ Internationally mobile investors typically distribute their capital across developed and emerging markets to increase returns and lower risk by choosing investments whose returns are relatively uncorrelated (for example, Errunza and Pabmanabhan 1988; Harvey 1993). At all levels of development, however, unchecked rent-seeking lower returns and deters investment. By failing to protect investor rights, states lose out on investment capital, particularly to markets at similar levels of development that often offer investors a similar risk-return profile and a similar opportunity to diversify away portfolio risk. Therefore, we expect that governments feel the most pressure to protect investors when countries at a similar development level protect investors from rent seeking. This leads us to our second hypothesis.

Hypothesis 2: Governments are more likely to adopt and enforce insider trading laws when countries of a similar development level have already done so.

We further believe that these domestic and international factors will condition one another. For any given electoral rule, we expect that increased competition in capital markets will increase the level of observed investor protection. Likewise, for any given level of competitive pressure we expect that more majoritarian electoral rules will increase the level of investor protection. If our tests were aimed at a continuous measure of investor protection, we would not expect an interaction between international competition and domestic politics. However, we are interested in the adoption and initial enforcement of insider trading laws, both of which we operationalize with dichotomous variables in our empirical tests (see below). Thus, what we observe is whether or not $W_{\mathrm{p}}$ gets above a discrete threshold, regardless of whether $W_{\mathrm{p}}$ is primarily a function of international or domestic pressures. To put this more concretely, we expect that the impact of electoral law will diminish when international competition is fierce, because governments running for reelection under all sorts of electoral rules will feel sufficient pressure to adopt and enforce insider trading laws. Likewise, we expect that the influence of international competition will diminish when governments are seeking office under relatively majoritarian electoral laws, where relatively slight competition will be enough to move government to ban insider trading. This motivates a third set of hypotheses.

Hypothesis 3a: The impact of electoral law on the adoption and enforcement of insider trading laws will diminish as competitive pressures increase.

Hypothesis 3b: The impact of competitive pressures on the adoption and enforcement of insider trading laws will diminish in countries with relatively majoritarian electoral laws.

\footnotetext{
15 This is a similar logic to that used to describe a competitive diffusion variable used in Simmons and Elkins (2004). Of course, similarities in development level is not the only way to conceptualize the extent to which countries compete for capital, though we do think it is the most important one. Cultural and linguistic similarities, for example, surely shape the pattern of investment flows. In our empirical analysis we control for geographic proximity as a way of controlling for some of these alternative mechanisms. Ideally, we would prefer to construct a measure based on the actual flows of portfolio investment to assess the extent to which countries compete for capital. Such data is unavailable for most countries in most years of our sample, however. While there is more data available for FDI flows, this data also lacks sufficient coverage to construct a meaningful variable for most countries in most years of our sample.
} 


\section{Insider Trading Laws}

Insider trading occurs when an actor with access to non-public information uses that information to trade corporate securities. Non-public information is typically ascertained via a trader's position inside of a firm-as a controlling shareholder (often including foreign direct investors), director, manager, or other privileged employee-where they may have special knowledge of unannounced takeover bids, upcoming earnings reports, or any other information that may impact the value of shares. There are several reasons, both substantive and methodological, why insider trading makes a useful policy domain.

First, insider trading highlights the distributional conflict at the heart of the political competition over investor protection. By definition, not every trader has equal access to non-public information; only certain actors enjoy a unique advantage. When insider trading is banned, information traders-traders who invest in knowledge of publicly available information-can profit from the informational advantage gleaned from their research. When insider trading is allowed, however, insiders will routinely beat information traders in the market, thereby undermining those traders' material incentives to participate in securities trading (Goshen and Parchomovsky 2001; summarized in Beny 2005, 2007). In this way, insider trading pits the interests of outside investors against those of corporate insiders. ${ }^{16}$

The distributional consequences of insider trading are not confined to information traders. By reducing the expected returns for outside holders of securities and thereby lowering the demand for corporate securities by outside investors, allowing unfettered insider trading increases firms' cost of capital (for example, Bhattacharya and Daouk 2002; Beny 2005). ${ }^{17}$ This has welfare implications for existing outside shareholders whose portfolio values fall, entrepreneurs who are less able to raise new funds on capital markets, and the non-shareholding public who has an implicit interest in a healthy capital market and its ability to finance the "real" economy. Insider trading laws are therefore similar to a larger set of investor protections that promote financial development at the expense of insider's rent seeking opportunities.

A second reason to study insider trading laws is that these laws have become an increasingly common feature of national-and in the case of the European Union, transnational-regulatory landscapes. The first recognizable insider trading law was enacted as part of the Securities and Exchange Act of 1934 in the United States, which banned a variety of profit making trades by corporate insiders. Other countries were initially slow to adopt insider trading prohibitions. Very few countries-the United States, Canada, and France-adopted insider trading laws prior to the fall of Bretton Woods and the subsequent dismantling of capital controls in the early 1970s. By 1980, six more countries had adopted an insider trading law. It was not until the 1990s, however, that the policy truly expanded; 57 countries adopted an insider trading law during the 1990s. The diffusion of enforcement follows a similar pattern, though there are far fewer enforcers than adopters.

A third reason to explore the diffusion of insider trading laws is that, unlike dependent variables used in previous studies of investor protection, the relatively recent spread of insider trading prohibitions allows us to observe the exact political and economic conditions under which these laws were first adopted and

\footnotetext{
${ }^{16}$ Empirically, Bushman et al. (2005) demonstrate that analyst following-a proxy for the degree of investor interest in a firm-increases after the enforcement of an insider trading ban, particularly in emerging markets. Similarly, Bris (2005), Bhattacharya and Daouk (2002) and Beny (2005, 2007) all find that insider trading laws increase stock market liquidity.

17 Beny also finds that more stringent insider trading laws correlate with more accurate stock prices.
} 
enforced. This stands in stark contrast to the more commonly used La Porta et al. (1998) data set, which captures a cross-sectional snapshot of corporate governance policy in 1997, but cannot tell us what political-economic conditions were in place when these policies were first adopted. This can be problematic for theories that focus on political institutions or economic factors because the conditions at the date of observation may not be the same as those in place when the policies were set. Bebchuk and Roe (1999) have noted strong theoretical reasons for the considerable path dependence observed in the data, which further obscures the link between a cross-sectional snapshot of policy and the political economic factors that give way to its rise. ${ }^{18}$ Focusing on insider trading laws thus gives us unique insight into the political determinants of investor protection. Only the United States' banning of insider trading in 1934 predates our sample. This allows us to effectively avoid the problem of unaccounted for path dependence.

In sum, insider trading provides us with an empirical domain (i) that highlights the political competition over investor protection; (ii) that has become an increasingly prominent feature of national regulatory schemes; and (iii) that provides unique insight into the precise political-economic conditions that promote investor protections.

\section{Research Design Sample}

To test the validity of our hypotheses, we construct a country-year data set from the years 1951 to 1999 for the 84 democracies with functioning stock markets, though missing data on the independent variable reduces our sample to 57 countries. ${ }^{19}$ We limit ourselves to democracies because electoral proportionality has little meaning in a nondemocratic state. We define democracy very leniently, allowing any country with a polity score over 0 (polity scores range from -10 to 10) into our sample. ${ }^{20}$ Our sample is limited to the years 1951-1999 because data on the dependent variables are only available through 1999 and data on some of our independent variables begin in 1950, which, because of lagged variables, effectively begins our sample in 1951. Not every country is represented in every year because (i) democracy scores fluctuate over time; and (ii) not every country has an operating stock exchange for the entire period.

European Community Insider Trading Directive (ECITD) of 1989 prohibits insider trading in all EU member states. Under ECITD, national lawmakers in the European Union were expected to adopt insider trading prohibitions by 1992, though in practice several of these countries already had laws in place and others did not adopt insider trading laws until several years later. Enforcements are unaffected by the ECITD. To accommodate this, we include a Europe dummy variable to allow for a separate European intercept. ${ }^{21}$

\footnotetext{
${ }^{18}$ Other data sets including Pagano and Volpin (2005), which extends La Porta, et al.'s measure to the years 1993-2002, and Djankov, McLiesh, and Shleifer (2007), which measures creditor protections from 1978 to 2002, attenuate this problem, but even in these data sets much of the information contained in the variable relates to policies enacted before the observation period begins.

${ }^{19}$ Our sample for insider trading law adoption and enforcement use a different set of 57 countries. It is merely be coincidence that the six countries that, for various reasons, are included in our model of insider trading law enforcement but not adoption (Armenia, Moldova, Slovak Republic, South Africa, Sweden, United States) are matched exactly by six countries that feature in our model of insider trading law adoption by not enforcement (Bolivia, El Salvador, Malawi, Namibia, Peru, Ukraine).

${ }^{20}$ Using higher thresholds does not change our core results.

21 The separate Europe intercept turns out to be inconsequential to our estimates. In unreported robustness checks we found very similar results using a Europe-only sample as well as a non-European sample. These regressions are available from the authors on request.
} 


\section{Dependent Variables}

We use two dependent variables, one that notes the year of insider trading law adoption (Adoption) and one that notes the initial enforcement (Enforcement). Both measures are dichotomously coded such that "1" denotes either the adoption or enforcement of a law and " 0 " denotes that such an event has not yet taken place. These data were taken from Bhattacharya and Daouk (2002).

\section{Independent Variables}

Our theory predicts that more proportional systems are less likely to adopt and enforce insider trading laws. We operationalize proportionality using a measure of median district magnitude taken from Golder (2005). Golder's data shows the median number of elected representatives from each district. The measure ranges from 1 in the case of majoritarian systems such as the United States to a maximum of 150 for the Netherlands. We subtract 1 from Median District Magnitude (making the minimum observed value equal to 0, rather than 1) to make the coefficients reported in the regression tables more meaningful in light of our use of interaction terms. ${ }^{22}$ Using this measure has an advantage over the dichotomous proportional/majoritarian indicator variable used in Rogowski and Kayser's (2002) study of price levels and the trichotomous measure used in Pagano and Volpin's (2005) study of shareholder voting rights. In particular, Median District Magnitude allows us to capture the considerable variation that exists among proportional systems. For example, at various points throughout the sample, Chile, Panama, and Thailand have a median district magnitude of 2 while the Netherlands, which pools candidates in a single, national district, has a district magnitude of 150.23 This is a meaningful difference that would be lost using a dichotomous or trichotomous measure. In order to capture the extent of competition between countries at similar development levels, we construct a variable that notes the percentage of countries at similar development levels that have banned insider trading in year t. We define similar development level by calculating the difference in the $\log$ of GDP per capita (in \$millions) for every dyad of countries with a stock exchange, and include those countries with GDPs per capita that are similar enough that the absolute value of the difference in logged GDP per capita is less than $.3 .^{24}$ For the most part, this produces intuitive pairings. Calculating Poland's value in 1999 uses information from 21 countries, including Brazil, South Africa, Slovakia, Russia, Lebanon, Mexico, and Thailand. Computing a score for the United States in 1999 includes data from Australia, Austria, Canada, Denmark, Iceland, Kuwait, Luxembourg, Netherlands, Norway, Singapore, and Switzerland. This variable also reflects development over time. Computing a value for Ireland in 1979 uses information from Portugal, Venezuela, Argentina, Spain, Singapore, and Greece. Ireland's 1999 score uses information from 28 countries including Austria, Canada, France, and the Netherlands. Despite the occasionally odd pairing (Kuwait, for example, does not have a stock market that is similar to the American stock market in any meaningful sense, despite the similarities in GDP per capita), we believe this

\footnotetext{
${ }^{22}$ This transformation is made solely to make the regression tables slightly more meaningful and makes no change to our findings, which, in any event, are better established by graphs of conditional coefficients.

23 Prior to 1956 Golder reports a district magnitude of 100 for the Netherlands.

${ }^{24}$ The benefit of this construction is that it does not necessarily increase simply because a country has many peers in its development level group. Using a cutoff of .3 is arbitrary, and was selected because it created reasonable pairings for most country-years we examined. In practice, using different cutoffs produces similar results.
} 
technique has produced valid measures of the extent to which a country faces competitive pressures from policies in its development level cohort.

\section{Control Variables}

It is possible that the adoption and enforcement of insider trading is affected by a number of factors whose exclusion may introduce omitted variable bias into our estimates. We include several measures to control for these alternative explanations.

We include a variable labeled Proximity Diffusion along with its interaction with Median District Magnitude. Proximity Diffusion is constructed as a count of countries that have adopted a ban on insider trading, weighted by the inverse of the log of the distance between countries' capital cities. ${ }^{25}$ Thus, this variable takes on larger values when extant insider trading laws are clustered in proximate countries and smaller values when these laws are clustered in more distant countries. We include this variable because it is likely that there are other paths of competitive pressures beyond those captured in Development Level Diffusion, and equally likely that there are alternative vectors of diffusion beyond competitive pressures (see Simmons and Elkins 2004). In unreported robustness checks we modeled several of these alternatives individually and found that in each case (i) none of the alternative explanations produced results that confounded the relationship we find with Development Level Diffusion, and (ii) Development Level Diffusion appeared to be the dominant vector of diffusion in terms of statistical and substantive significance.

To control for La Porta, et al.'s legal heritage theory, we include a dichotomously coded variable that is coded " 1 " for countries whose legal systems are based on common law and "0" otherwise (Common Law). Controlling for legal heritage is important because countries with majoritarian electoral laws also tend to have legal systems based on common law, which La Porta et al. argue increases the likelihood that states protect the rights of investors. Similarly, countries with higher district magnitudes are also more likely to have a larger number of veto players in government, which are known to stifle policy changes, presumably including the adoption of insider trading laws. We control for the number of Veto Players using Polcon_iii from Henisz's Database of Political Constraints. ${ }^{26}$ As mentioned above, we include a dichotomous indicator coded " 1 " for European countries and " 0 " otherwise, allowing for a separate intercept for countries that were or may have been impacted by ECDIT. We also control for several variables that have been shown in related literature to influence levels of investor protection. These controls are: democracy, which is measured using the Polity IV data set, $\log$ of GDP, which is introduced at a 1-year lag and is taken from the Penn World Tables data set and the $\log$ of GDP per capita, which is also introduced at a 1-year lag and is taken from the Penn World Tables data set. ${ }^{27}$

We also allow for a separate intercept for Israel by including a dichotomous indicator variable coded 1 for Israel and 0 otherwise. Our model does a poor job of explaining Israel, whose large district magnitude (2nd highest in our sample) and early adoption and enforcement of insider trading (12th earliest adopter

\footnotetext{
25 In unreported robustness checks, using measures of contiguity as a substitute for the distance between capitals yields comparable results.

${ }^{26}$ Henisz 2008. We use Polcon_iii instead of Polcon_iv because the latter includes measures of subnational units of government and judicial independence, neither of which reflect our theoretical reasons for including veto players in our analysis. We prefer the polcon variable to the checks variable taken from Beck et al. (2001) because the latter only extends back to 1975, well after countries began adopting and enforcing insider trading laws.

27 Introducing or omitting these variables is inconsequential to our results. Models excluding these variables are available from the authors on request.
} 
and 7th earliest enforcer) make it an outlier in our dataset and gives it significant leverage over our results. To be clear, including Israel in our sample without the separate intercept produces a model with significantly less robust results. 28

Our baseline model specification reads as follows:

\begin{tabular}{|c|c|}
\hline doption/Enforcement & $\begin{aligned}= & \beta_{0}+\beta_{1} * \text { Median District Magnitude }_{\mathrm{it}} \\
& +\beta_{2} * \text { Development Level Diffusion }_{\mathrm{it}-1} \\
& +\beta_{3} * \text { Median District Magnitude }_{\mathrm{it}} \\
& \left.* \text { Development Level Diffusion }_{\mathrm{it}-1}\right) \\
& +\beta_{4} * \text { Proximity Diffusion }_{\mathrm{it}-1} \\
& +\beta_{5} * \text { Median District Magnitude }_{\mathrm{it}} \\
& \left.* \text { Proximity Diffusion }_{\mathrm{it}-1}\right) \\
& +\beta_{6} * \text { Democracy }_{\mathrm{it}}+\beta_{7} * \text { Veto Players }_{\mathrm{it}} \\
& +\beta_{8} * \text { Log GDP }_{\mathrm{it}-1}+\beta_{9} *{\text { Log GDP } \text { per capita }_{\mathrm{it}-1}}+\beta_{10} * \text { Common Law }_{\mathrm{i}}+\beta_{11} * \text { Israel }_{\mathrm{i}} \\
& +\beta_{12} * \text { Europe }_{\mathrm{i}}+\varepsilon_{\mathrm{it}}\end{aligned}$ \\
\hline
\end{tabular}

\section{Analyses and Results}

Given the nature of our data and hypotheses, the appropriate estimation technique is event history analysis using a single failure-event per cross-section data structure. We report results using the commonly used Cox proportional hazards estimator, with data disaggregated ("grouped") by the country-year. ${ }^{29}$ The advantages and disadvantages posed by the Cox estimator are well known in the political science (see Box-Steffensmeier and Jones 1997, Box-Steffensmeier and Jones 2004; Box-Steffensmeier and Zorn 2002). ${ }^{30}$ To demonstrate that our results are not an artifact of our choice of estimators, we supplement our main models with robustness checks using a binary time series cross-sectional model with a clog-log link function, as well as fully parametric models specified with Weibull and log-normal distributions. The results are effectively the same across all specifications.

A requirement of event history models is the specification of an underlying time counter. This is straightforward in our models of insider trading law enforcement: the counter starts in the year of insider trading law adoption. Starting at the date of adoption also has the advantage of ensuring that our findings

\footnotetext{
${ }^{28}$ Similar results are obtained if we exclude Israel from the sample. To be clear, however, including Israel in our sample but not allowing a separate intercept produces a model with less robust results. We don't control for government partisanship in the reported models. We do this for two reasons. First, the best available measure, the trichotomous measure of government partisanship from the database of political institutions, has obvious and wellappreciated limitations. Second, this variable is only coded for years beginning in 1975 , considerably after the beginning of our period of observation. Thus including this variable requires us to eliminate several early law adoptions and enforcements. This non-random elimination of observations introduces bias that is not justified, given the explanatory limitations of the variable itself. In unreported robustness checks we find similar, though not identical, results from models using the variable.

${ }^{29}$ Organizing the data by country-year is not the only way of organizing the data. We could also consider each spell of democratic government as its own cross section. In this way, Pakistan, for example, would enter the regression analysis separately four times, once for every time its polity score crossed zero during the sample. Reorganizing the data in this way does not alter our findings.

${ }^{30}$ We report regressions using the Breslow method of dealing with ties. Our results are robust to estimations using either the Efron or Breslow method. A further complication posed by the use of a Cox model is the proportional hazards assumption. As noted by several authors, violations of this assumption can lead to biased results (Box-Steffensmeier, Reiter, and Zorn 2003). Diagnostic tests examining the scaled Schoenfeld residuals fail to reject the null hypothesis that the proportionality assumption is satisfied.
} 
in our enforcement models capture an entirely different set of data than our adoption model. Because one sample begins at the moment the other ends, there can be no overlap. The coding is less clear for our models of insider trading law adoption. While many countries began stock exchange operations during nineteenth and twentieth century, other states had active stock markets for centuries before they adopted an insider trading law. Substantively, it is not clear whether the existence of a pre-modern stock market should matter for our analyses. Our solution is to begin the counter at the start of the postwar era or in the first year of stock market operations if trading began more recently than 1946 .

The interpretation of Cox model coefficients is slightly different from other commonly used estimators. The directionality of the coefficients is similar to OLS coefficients: positive coefficients suggest that an increase in a variable increases the probability of failure (in the case, failure means the adoption or initial enforcement of insider trading laws); negative coefficients indicate the opposite. More precisely, significant variables impact the duration time by increasing or decreasing the hazard, which captures the likelihood of experiencing a failure event, which in this case is the adoption or initial enforcement of an insider trading law. To find the change in the hazard affected by an $X$ unit change from a baseline value of $\delta$ we employ the standard transformation, ${ }^{31}$

$$
\text { \%increase in } h(t)=100 *[\exp (\beta *(\delta+X))-\exp (\beta * \delta)] / \exp (\beta * \delta)
$$

We include plots of the substantive effects of a shift in our independent variables along with our coefficient estimates.

\section{Model 1: Adoption of Insider Trading Laws}

Our first analysis examines the adoption of insider trading laws, (the results are shown in Model 1 in Table 1). The estimates, and the associated conditional coefficients described below, lend support to all three of our hypotheses. The regression coefficient on Median District Magnitude is statistically significant (though only at the .1 level) and negative, indicating that when Development Level

TABLe 1. Cox Proportional Hazards Models

\begin{tabular}{|c|c|c|c|c|}
\hline \multirow[b]{2}{*}{ Variable } & \multicolumn{2}{|c|}{$\begin{array}{l}\text { Model } 1 \\
\text { Adoption }\end{array}$} & \multicolumn{2}{|c|}{$\begin{array}{c}\text { Model } 2 \\
\text { Enforcement }\end{array}$} \\
\hline & Coefficient & $S E$ & Coefficient & $S E$ \\
\hline Median District Magnitude & -0.039 & $0.022 *$ & -0.230 & $0.101 * *$ \\
\hline Development Level Diffusion (lag) & -0.572 & 1.002 & 3.455 & $1.960 *$ \\
\hline Dev. Level Diff. (lag) $\times$ Med. Dist. Mag. & 0.087 & $0.040^{* *}$ & 0.219 & $0.114^{*}$ \\
\hline Proximity Diffusion (lag) & 0.377 & $0.134 * * *$ & -0.202 & 0.166 \\
\hline Prox. Diff. (lag) × Med. Dist. Mag. & -0.004 & 0.003 & 0.001 & 0.007 \\
\hline Democracy & -0.052 & 0.173 & -0.246 & 0.161 \\
\hline Veto Players & -1.208 & 1.326 & 2.871 & 1.859 \\
\hline Log GDP (lag) & -0.083 & 0.103 & 0.662 & $0.166^{* * *}$ \\
\hline Log GDP Per Capita (lag) & 0.510 & $0.295^{*}$ & -0.076 & 0.346 \\
\hline Common Law & 0.488 & 0.412 & -0.082 & 0.569 \\
\hline Israel & 3.573 & $1.900^{*}$ & 14.180 & $5.253 * * *$ \\
\hline Europe & 0.092 & 0.414 & 0.928 & $0.540 *$ \\
\hline$N$ & 838 & & 368 & \\
\hline Failures & 46 & & 28 & \\
\hline Log pseudolikelihood & -103.59938 & & -64.657649 & \\
\hline
\end{tabular}

(Notes. $* p<.100, * * p<.050, * * * p<.001$.

\footnotetext{
${ }^{31}$ See Box-Steffensmeier and Jones (2004:60).
} 
Diffusion is equal to zero the proportionality of electoral rules has a significant and negative impact on the likelihood of adopting an insider trading law. The regression coefficient on Development Level Diffusion is negative and statistically insignificant, indicating that Development Level Diffusion is not a significant factor in countries that use winner-takes-all electoral laws-that is, when Median District Magnitude is equal to zero. However, the positive and significant coefficient on the interaction of Development Level Diffusion and Median District Magnitude suggests that (i) competitive pressures have a larger, positive impact in countries with more proportional electoral rules; and (ii) that electoral rules have a smaller impact as competitive pressures increase.

Because our results indicate a statistically significant interaction between Median District Magnitude and Development Levels Diffusion, conditional coefficients can give us a better sense of our findings (see Figures 3 and 4). We graph the conditional coefficients for a variable evaluated at a range of the conditioning variable that corresponds to the 10th through the 90th percentile of that variable in the sample used in that model. We graph three lines in each figure: a point estimate and the upper and lower bounds of a $90 \%$ confidence interval. ${ }^{32}$ When all three lines are on the same side of zero, the point estimate is statistically significant at the .1 level. When the upper and lower bounds are on different sides of zero the point estimate is insignificant at the .1 level.

Figure 3 shows the conditional coefficients for Median District Magnitude at a range of values of Development Level Diffusion. Notice that the conditional coefficient for Median District Magnitude is statistically significant and negative (both upper and lower bounds are below zero) at low values of Development Level Diffusion. However, Median District Magnitude becomes statistically insignificant as Development Level Diffusion increases even slightly above 0. This indicates that countries with proportional electoral rules are less likely to ban insider trading

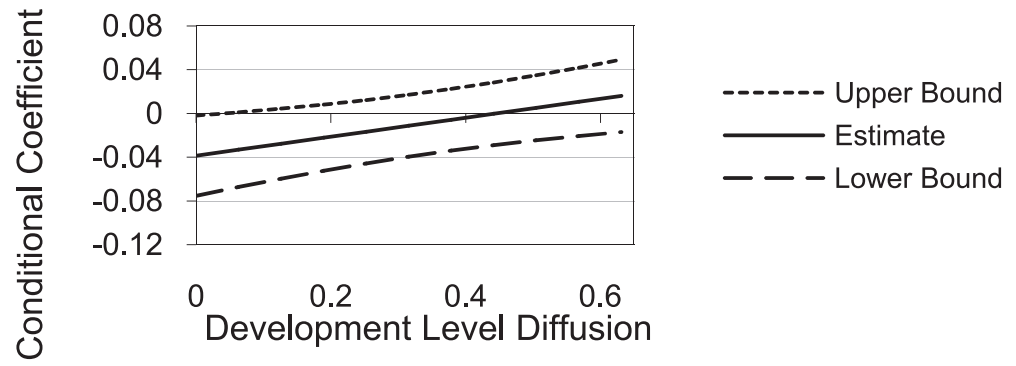

FIg 3. Conditional Coefficient for Median District Magnitude

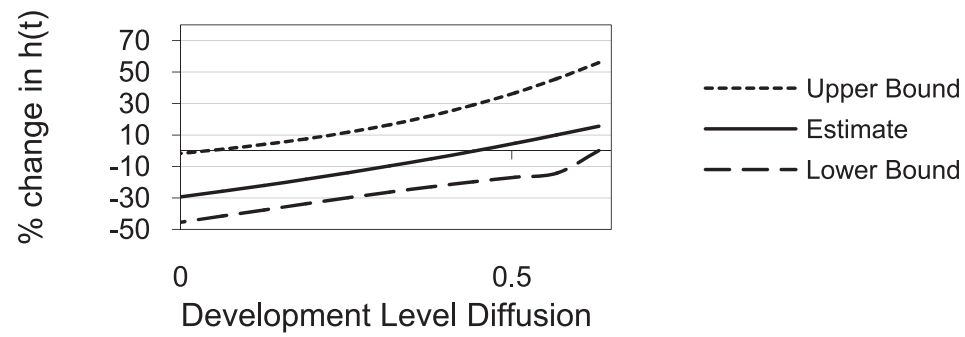

FIG 4. Conditional Substantive Effects of a change in Median District Magnitude from the 25th-75th percentile

\footnotetext{
${ }^{32}$ These values were generated using the lincom command in Stata 9.2.
} 
but that this effect fades quickly as competitive pressures increase, which is line with Hypotheses 1 and 3a.

To show the substantive effects of Median District Magnitude on the adoption of insider trading laws, Figure 4 converts the coefficients from Figure 3 into substantive effects using the formula noted above. In the graph, we show the conditional substantive impact of a shift in district magnitude from 0 to 9 , which corresponds to a move from the 25th to the 75th percentile of Median District Magnitude in the sample. As can be seen, at very low levels of Development Level Diffusion, a shift in Median District Magnitude from 9 to 0 has the substantive impact of increasing the likelihood of an insider trading law being adopted by $2 \%$.

Figure 5 shows the conditional coefficients for Development Level Diffusion at a range of values for Median District Magnitude. The conditional coefficients for Development Level Diffusion are insignificant at low and moderate levels of Median District Magnitude but become statistically significant and positive at values of Median District Magnitude at or above 43, which is roughly the 88th percentile of the observed data in this sample. This pattern supports Hypotheses 2 and 3b, suggesting that countries facing competitive pressures will be more likely to adopt insider trading laws, particularly in countries with highly proportional electoral laws.

Figure 6 shows the conditional substantive effects for Development Level Diffusion. We show the conditional substantive effect of a shift from the 25th to 75 th percentile of values in 1999, which corresponds to a shift from .07 to .35 . The statistically significant range of point predictions for Development Level Diffusion vary from a $174 \%$ increase in the baseline hazard when Median District Magnitude is equal to 48 up to a $783 \%$ increase in the baseline hazard when Median District Magnitude is equal to 95 . The confidence interval is extremely large, particularly at higher values of Median District Magnitude. At values of Median District Magnitude of 9 , the $90 \%$ confidence interval runs from $47.2 \%$ to $5,195 \%$. Thus, while our results allow us to say something about the directionality and statistical significance of Development Level Diffusion, there is relatively little we can say about the magnitude of its substantive effect, particularly in countries with highly proportional electoral systems where competition's impact is the largest.

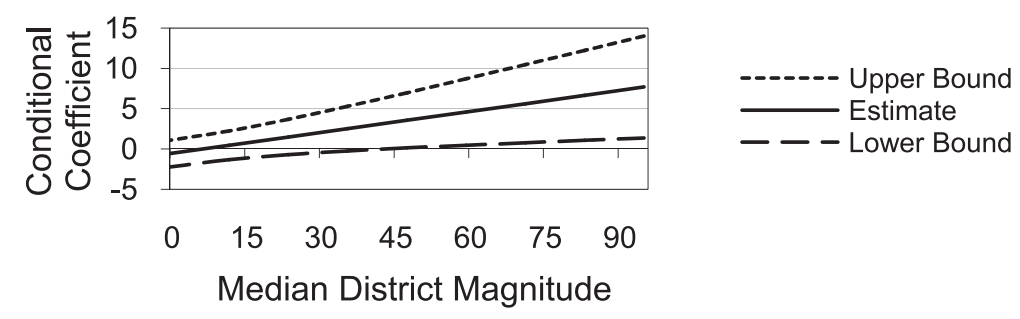

FIG 5. Conditional Coefficient for Development Level Diffusion

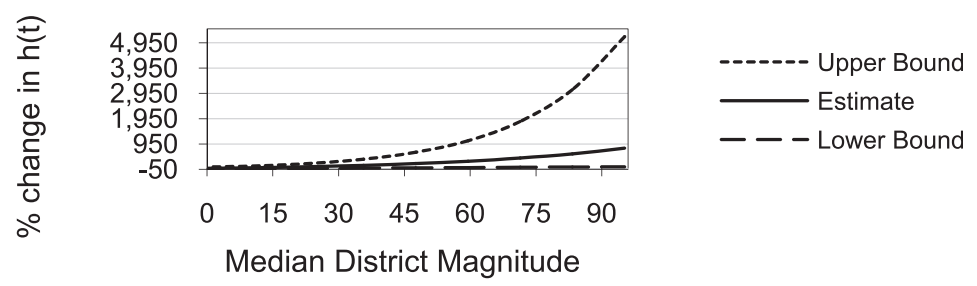

FIG 6. Conditional Substantive Effects of a change in Development Level Diffusion from the 25 th-75th percentile 


\section{Model 2: Enforcement of Insider Trading Laws}

Model 2 replicates Models 1 using the initial enforcement of an insider trading law as the failure event (see Table 1). To reiterate from above, the sample in these models begins at the year of insider trading law adoption and ends in the year that law is first enforced. The results here are similar to those in reported for Model 1. Median District Magnitude is again negatively signed and statistically significant, indicating that more proportional electoral laws imply longer times until an insider trading law is enforced, at least in the absence of any competitive pressures. The interaction between Median District Magnitude and Development Level Diffusion is positively signed and statistically significant. In other words, as the proportionality of the electoral rule increases, the impact of competitive diffusion decreases, and vice versa. Likewise, the effect of electoral rules on enforcement is attenuated by competitive pressures. The coefficient for Development Level Diffusion is positively signed and statistically significant. These regression coefficients are consistent with our findings in Model 1. To ascertain the full impact of Median District Magnitude and Development Level Diffusion we again refer to conditional coefficients and conditional substantive effects, which are plotted in Figures $7-10$.

Figure 7 shows the conditional coefficients for Median District Magnitude using regression estimates from Model 2. As with Model 1, the conditional coefficients for Median District Magnitude begin negative and statistically significant and move toward zero as Development Level Diffusion increases, eventually reaching statistical insignificance. Unlike in Model 1, however, the conditional coefficients here remain statistically significant until roughly $68 \%$ of a country's development cohort has adopted a ban on insider trading. These results support Hypothesis 1 , that countries with more proportional electoral laws are less likely to enforce insider trading laws, and Hypothesis 3a, that the impact of Median District Magnitude is declining in the level of competitive diffusion.

Figure 8 shows the substantive effects of a move from a Median District Magnitude of 9 to a Median District Magnitude of 0 at a range of values for Development

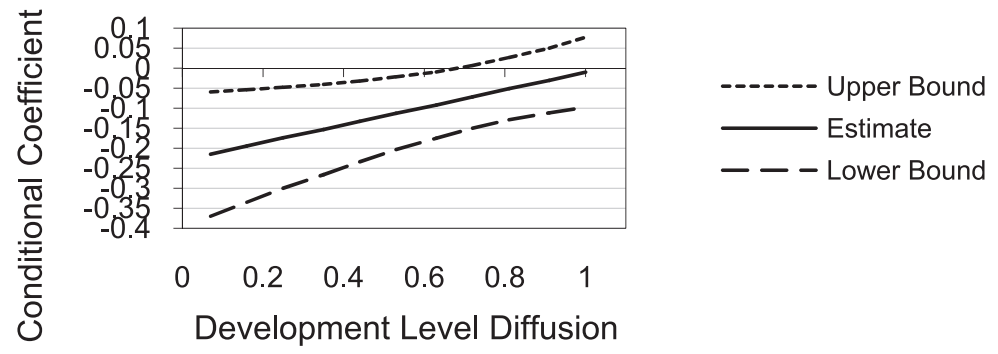

FIG 7. Conditional Coefficients for Median District Magnitude

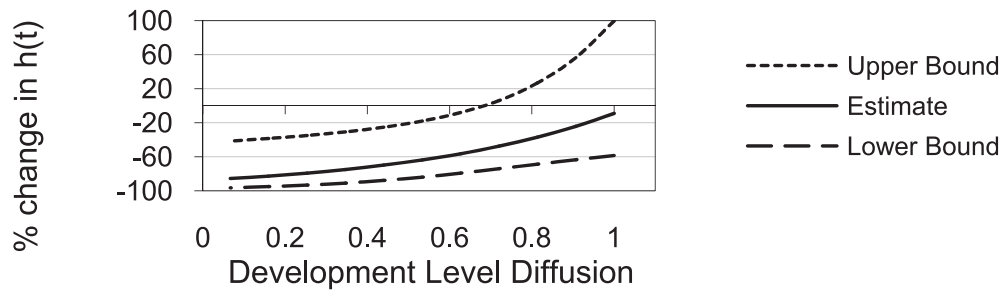

FIG 8. Conditional Substantive Effects of a change in Development Level Diffusion from the 25th-75th percentile 


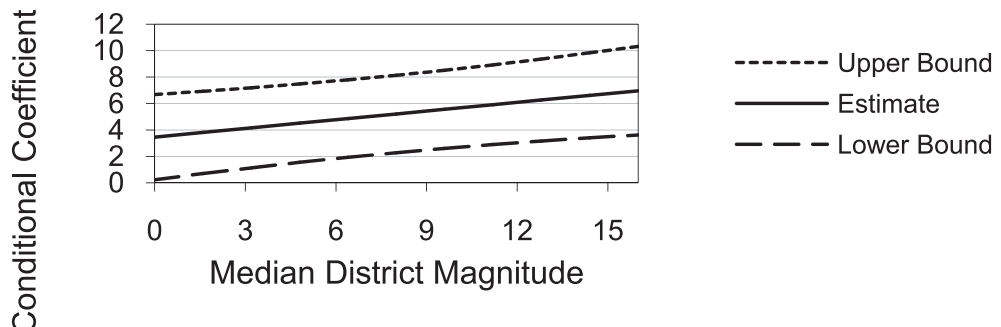

FIG 9. Conditional Coefficient for Development Level Diffusion

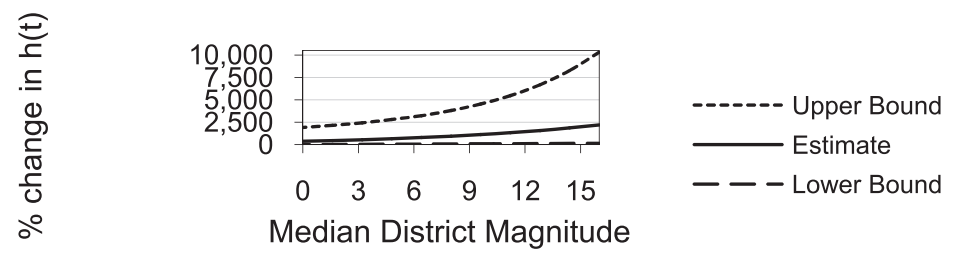

FIg 10. Conditional Substantive Effects of a change in Development Level Diffusion from the 25th-75th percentile

Level Diffusion. In the absence of competitive pressures (the 1st percentile of Development Level Diffusion is .16) a shift in Median District Magnitude from 9 to 0 has the effect of raising the baseline hazard by $82 \%$. As Development Level Diffusion increases this impact lowers, eventually reaching $56 \%$ at values of Development Level Diffusion of .63, before slipping into statistical insignificance. As with the conditional substantive effects plotted in Figure 6, the $90 \%$ confidence interval is quite large.

Figure 9 shows the conditional coefficients for Development Level Diffusion. Like the regression estimates reported in Table 1, the conditional coefficients plotted in Figure 9 indicate that Development Level Diffusion is statistically significant and positive over the entire plotted range. Moreover, the coefficient rises substantially. Over the 10-90th percentile range of Median District Magnitude, the coefficient for Development Level Diffusion rises from 3.45 to 6.96. As before, these finding suggests support for Hypotheses 1 and $3 \mathrm{~b}$.

Figure 10 shows the conditional substantive effects of a shift in Development Level Diffusion from the 25th percentile in the sample (.382) to the 25th percentile (.833) evaluated at the 10-90th percentile range of Median District Magnitude. The substantive impact of Development Level Diffusion is statistically significant and positive over the entire range, and rapidly increasing in Median District Magnitude. Over the full range the point estimate ranges from $374 \%$ (Median District Magnitude of 0) to 2,202\% (Median District Magnitude of 16). As before, however, the $90 \%$ confidence interval is exceedingly large. At its largest span (Median District Magnitude = 16) it ranges from $409 \%$ to $10,322 \%$.

In sum, we find support for all of our hypotheses in both our models of insider trading law adoption and insider trading law enforcement. In both cases, increases in Median District Magnitude prolong the failure time, especially when competitive diffusion is weak. Increases in Development Level Diffusion shorten the failure time, particularly in countries with proportional electoral rules. While it does appear that both variables have a greater impact on the enforcement, rather than the adoption, of insider laws, the extremely wide confidence intervals precludes our ability to say so definitively. 


\section{Models 3-8: Robustness Checks}

We subject our data to several alternative estimations to determine the robustness of our results. The results of these robustness checks are reported in Table 2. ${ }^{33}$ Models 3 and 4 estimate models of insider trading law adoption and enforcement, respectively, using binary time series cross-sectional (BTSCS) methods that are outlined in Beck, Katz, and Tucker (1998) and are commonly used to estimate models with grouped data such ours. We estimate our BTSCS using a clog-log link as suggested by Beck, Katz, and Tucker, though the results are substantively almost identical using a logit model. We include year dummies (excluded from the regression table) that are aggregated into 5-year spans in our regression. ${ }^{34}$ The results from these models lead to very similar results as the conclusion drawn from Models 1 and 2.

Models 5 and 6 reestimate Models 1 and 2, respectively, using a parametric estimator that stipulates a Weibull distribution to model the baseline hazard. The Weibull model, which is the most commonly used parametric estimator in the political science literature, assumes a monotonically increasing or decreasing baseline hazard. The results from Models 5 and 6 are substantially similar to models listed in the four previous models.

Finally, Models 7 and 8 reestimate Models 1 and 2, respectively, using a parametric model that specifies a log-normal distribution for the baseline hazard. The log-normal model, similarly to the log-logistic model, allows the baseline hazard to be non-monotonic, unlike the Weibull. Comparing Akaike Information Criterions, we found the log-normal model was a better fit to the data than the log-logistic. The results are consistent with those found earlier, though the coefficients are reported in accelerated failure time, which reverses the sign and changes the substantive interpretations.

Before concluding, we note that our control variables indicate some interesting findings. Most prominently, we find no effect for legal heritage in any model. While we hesitate to over-interpret non-findings, we do note that the insignificance of legal heritage in accounting for corporate governance policies once electoral rules are controlled for is consistent with Pagano and Volpin (2005). Intuitively, we find that GDP has an impact on enforcement, but not adoption, suggesting that the financial resources needed to detect and prosecute a case of insider trading is a barrier to enforcement in countries with smaller economies. Surprisingly, contra Beny (2008), we find no consistent effect for democracy, though this is likely explained by the fact that our sample excludes country-years with polity scores below 0 .

\section{Conclusions and Implications}

This paper asks why, in spite of all the welfare benefits that accrue from protecting investor rights, there is so much cross-national variation in the adoption and enforcement of policies like insider trading laws. To answer this question we have brought together two recent strands of comparative and international political economy work. We argue that both domestic political institutions and international competitive pressures bear on investor-related policy decisions. Only when the influences of both are considered simultaneously does a fuller picture emerge.

\footnotetext{
${ }^{33}$ We do not provide conditional coefficients or conditional substantive effects for these models, but such graphs are available from the authors on request.

${ }^{34}$ We aggregate the year dummies into 5-year chunks because the model would otherwise drop observations in years of the time counter in which no countries adopted or initially enforced their insider trading laws. Five-year spans were the smallest increment that allowed us to retain the same sample used in Models 1 and 2. Similar findings were obtained in unreported robustness checks that modeled duration dependence using splines or time trends.
} 


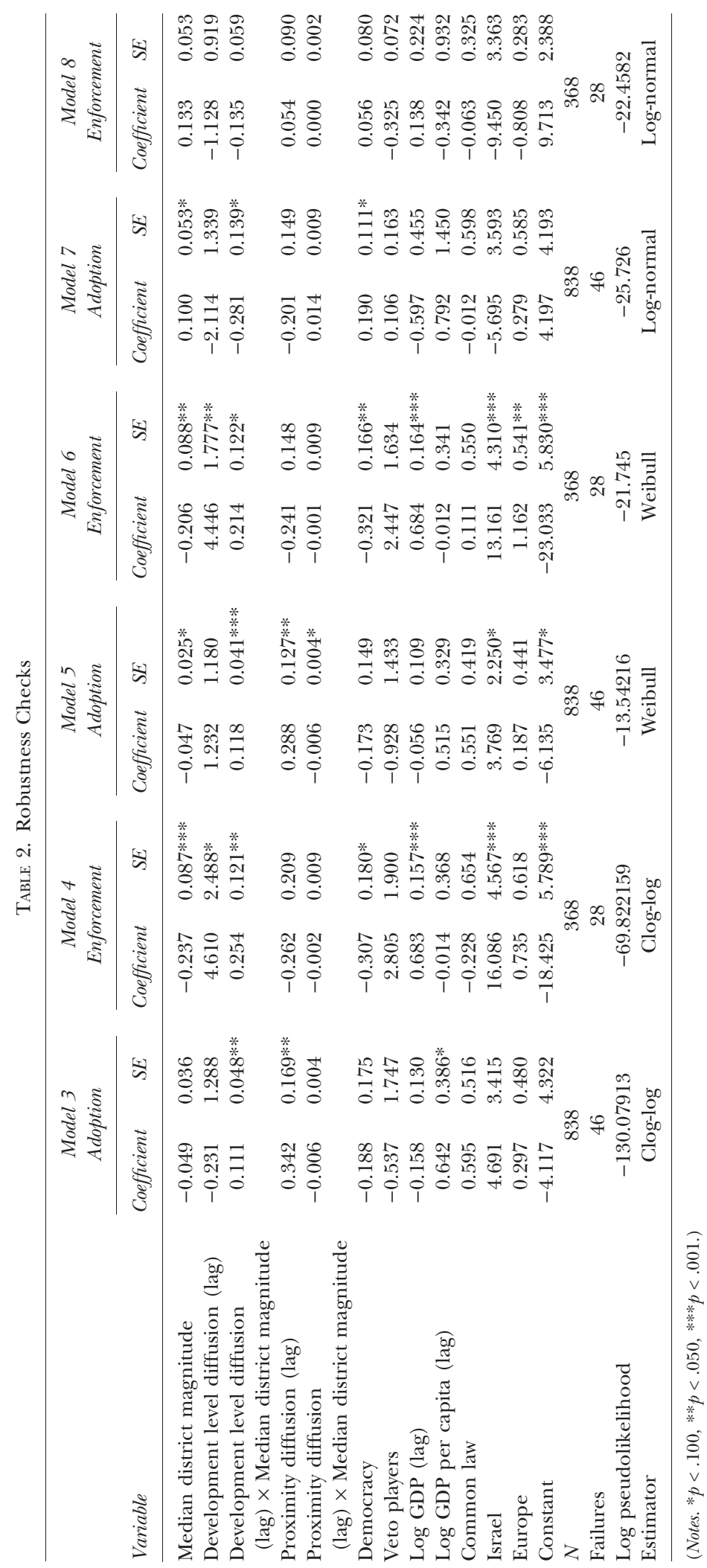


We have reported evidence in support of all three of our hypotheses. We found that (i) electoral rules do have a significant effect at both the adoption and enforcement stage, (ii) the policy choices made by countries at a similar development level, with which countries compete for investment capital, are a source of competitive pressure to adopt and enforce insider trading laws, and (iii) international competition conditions the impact of domestic institutions, and vice-versa. This finding is robust to the inclusion of variables meant to capture other sources of rising competitive pressures and to unreported robustness checks in which plausible alternative mechanisms of competitive diffusion are controlled for.

Our results provide strong evidence for a spatial diffusion process. For the reasons presented in this paper we believe there are good reasons to believe this diffusion is driven by international competition over capital. However, diffusion can occur via a number of channels and it is difficult to devise tests that clearly differentiate between these various channels. One alternative to our theory is that the adoption of insider trading laws is driven by norms-ideas that spread throughout the international community eventually reaching a "tipping point" after which they enjoy widespread acceptance (Finnemore and Sikkink 1998). We grant that it is possible that a similar process explains the spread of insider trading laws, and our statistical results can certainly be interpreted as evidence for such a process. However, while the spread of insider trading laws match a pattern consistent with the cascading of norms, it is not clear why it took so long for the norm to spread. The first instance of adoption was in the 1930s (the United States in 1934) and it was not until the more than 40 years later that adoptions began to spread more rapidly. It is not a coincidence, we believe, that the spread of insider trading laws only came after the relaxation of capital controls and heightened competition between states for mobile portfolio capital, beginning in the early 1970 s and accelerating through the 1980s and 1990s. The timing of the diffusion suggests to us prima facie evidence that increased competition over mobile capital was indeed the principal driving force behind the spread of prohibitions on insider trading.

This paper makes several contributions. First, we offer a framework for understanding the political determinants of investor protection that is simple, draws on works that are familiar to many political economists, addresses some of the shortcomings that we perceive in the literature, and which is supported by the data on insider trading regulations. Two elements of our theory are particularly important. First, by showing that the political pressures facing governments over investor protection policies such as insider trading laws are at least partly a function of policy decisions made in other countries, we have attempted to integrate the literature on investor protection with the considerable body of work on policy diffusion. Several authors have noted that there is an international competitive dynamic to investor protection, but such intuition is entirely absent in extant statistical models. We have offered a theory that shows how institutions and competitive pressures interact to define the incentives to enact investor protections. To that end, we see this paper not only as a complement to other works on investor protection, but also to works that have noted the interaction between domestic political institutions and policy diffusion.

Second, through our application of Rogowski and Kayser's work on electoral rules' impact on political accountability, we can account for the notable disparities in investor protection across democracies. Given the centrality of such variation to the larger enterprise of the investor protection literature, this is no small feature. While our causal mechanism linking electoral law to policy outcomes, as well as the policy outcome considered, is quite different, we do note that our findings are consistent with those made by Pagano and Volpin (2005) as well as Gourevitch and Shinn (2005). Moreover, if, as it appears, countries with 
proportional electoral laws systematically adopt policies that retard financial development, this should inhibit the entry of new firms to the domestic marketplace and may explain Rogowski and Kayser's finding that countries with more proportional electoral rules have higher price levels. In this sense our work is also a natural complement to work by Scartascini (2002).

We wish to conclude by noting that adopting and enforcing insider trading laws, while important, are nonetheless a relatively "cheap" form of investor protection. Indeed, part of insider trading laws' attractiveness for our purposes is that they do not directly impact corporate control, and are thus less susceptible to the argument made prominent in varieties of capitalism literature, that national economic outcomes may actually be better served, through reasons of complementaries and path dependence, by "inefficient" policies. Convergence on policies that do directly impact corporate control, such as changes in the way boards of directors are selected, or the extent to which management may avail themselves of various anti-takeover measures, have been slower going and have not, as of yet, shown the same degree of convergence as insider trading laws. Table 1 noted at the outset of this paper speaks to that, as do recent works by Culpepper (forthcoming-a,b), Khanna, Kogan, and Palepu (2006) and others. Nonetheless, we hope and suspect that the theoretical framework developed in this paper will be a useful tool in understanding future developments in this area.

\section{References}

Abramowitz, Alan I. (1991) Incumbency, Campaign Spending, and the Decline of Competition in U.S. House Elections. Journal of Politics (53): 34-56.

Aggarwal, Reena, Leora Klapper, and Peter Wysocki. (2005) Portfolio Preferences of Foreign Institutional Investors. Journal of Banking and Finance 29 (12): 2919-2946.

Alesina, Alberto, and Guido Tabellini. (1988) External Debt, Capital Flight and Political Risk. NBER Working Paper No. W2610.

Basinger, Scott J., and Mark Hallerberg. (2004) Remodeling the Competition for Capital: How Domestic Politics Erases the Race to the Bottom. American Political Science Review 98 (2): 261-276.

Bebchuk, Lucian. A., and Zvika Neeman. (forthcoming) Investor Protection and Interest Group Politics. Review of Financial Studies. Also available at SSRN: http://ssrn.com/abstract=1030355.

Bebchuk, Lucian. A., and Mark Roe. (1999) A Theory of Path Dependence in Corporate Governance and Ownership. Stanford Law Review 52 (1): 127-170.

Beck, Neal, Jonathan N. Katz, and Richard Tucker. (1998) Taking Time Seriously: TimeseriesCross-Section Analysis with a Binary Dependent Variable. American Journal of Political Science 42: 1260-1288.

Beck, Thorsten, Clarke, Alberto Groff, Philip Keefer, and Patrick Walsh. (2001) New Tools in Comparative Political Economy: The Database of Political Institutions. World Bank Economic Review 15 (1): 165-176.

Beck, Thorsten, Ross Levine, and Norman Loayza. (2000) Finance and the Sources of Growth. Journal of Financial Economics 58: 261-300.

Becker, Bo, and David Greenberg. (2003) The Real Effects of Finance: Evidence from Exports. mimeo, University of Chicago.

Beny, Laura N. (2005) Do Insider Trading Laws Matter? Some Preliminary Comparative Evidence American Law and Economics Review 7 (1): 144-183.

Beny, Laura N. (2007) Insider Trading Laws and Stock Markets Around the World: An Empirical Contribution to the Theoretical Law and Economics Debate. Journal of Corporation Law 32 (2): 237-300.

Beny, Laura N. (2008) The Political Economy of Insider Trading Legislation and Enforcement International Evidence. In U of Michigan Law \& Economics, Olin Working Paper No. 08-001. Available at SSRN: http://ssrn.com/abstract=304383 or DOI: $10.2139 /$ ssrn.304383.

Bernheim, B. Douglas, And Michael D. Whinston. (1986) Menu Auctions, Resource Allocation, and Economic Influence. Quarterly Journal of Economics 101 (1): 1-31.

Bhattacharya, Utpal, and Hazem Daouk. (2002) The World Price of Insider Trading. The Journal of Finance 57 (1): 75-108. 
Box-Steffensmeier, Janet M., and Bradford S. Jones. (1997) Time Is of the Essence: Event History Models in Political Science. American Journal of Political Science 41 (4): 336-383.

Box-Steffensmeier, Janet M., And Bradford S. Jones. (2004) Event History Modeling: A Guide for Social Scientists. Analytical Methods for Social Research Series. Cambridge: Cambridge University Press.

Box-Steffensmeier, Janet M., And Christopher J.W. Zorn. (2002) Duration Models for Repeated Events. The Journal of Politics 64: 1069-1094.

Box-Steffensmeier, Janet M., Dan Reiter, and Christopher J.W. Zorn. (2003) Nonproportional Hazards and Event History Analysis in International Relations. Journal of Conflict Resolution 47: 33-53.

Bris, Arturo. (2005) Do Insider Trading Laws Work? European Financial Management 11 (3): 267312.

Brooks, Sarah. (2005) Interdependent and Domestic Foundations of Policy Change: The Diffusion of Pension Privatization Around the World. International Studies Quarterly 49 (2): 273294.

Brooks, Sarah. (2007) When Does Diffusion Matter? Explaining the Spread of Structural Pension Reforms across Nations. The Journal of Politics 69 (3): 701-715.

Bushman, Robert M., Joseph D. Piotroski, and Abbie J. Smith. (2005) Insider Trading Restrictions and Analysts' Incentives to Follow Firms. The Journal of Finance 60 (1): 35.

Castro, Rui, Gian Luca Clementi, and Glenn MacDonald. (2004) Investor Protection, Optimal Incentives and Economic Growth. Quarterly Journal of Economics 119 (3): 1131-1175.

Cioffi, John W., And Martin Hopner. (2006) The Political Paradox of Finance Capitalism: Interests, Preferences, and Center-Left Party Politics in Corporate Governance Reform. Politics E Society 34 (4): 463.

Collier, Paul, Anke Hoeffler, and Catherine Pattillo. (2001) Flight Capital as a Portfolio Choice. World Bank Research Review 15 (1): 55-80.

Culpepper, Pepper D. (forthcoming a). Managers Usually Win: The Comparative Politics of Corporate Control. In Oxford Handbook on Business and Government, edited by David Coen, Wyn Grant, and Graham Wilson. Oxford University Press.

Culpepper, Pepper D. (forthcoming b) The Netherlands and the Myth of the Corporatist Coalition. mimeo, John F. Kennedy School of Government, Harvard University.

Demirgüç -Kunt, Asli, and Vojislav Maksimovic. (1998) Law, Finance, and Firm Growth. Journal of Finance 53: 2107-2139.

Dixit, Avinash, Gene Grossman, and Elhanen Helpman. (1997) Common Agency and Coordination: General Theory and Application to Government Policy Making. Journal of Political Economy 105 (4): 752-769.

Djankov, Simeon, Caralee McLiesh, and Andrei Shleifer. (2007) Private Credit in 129 Countries. Journal of Financial Economics 84 (2): 299-329.

Elkins, Zachary, Andrew T. Guzman, and Beth A. Simmons. (2006) Competing for Capital: The Diffusion of Bilateral Investment Treaties, 1960-2000. International Organization 60 (04): 811846.

Errunza, Vihang, and Prasad Padmanabhan. (1988) Further Evidence on the Benefits of Portfolio Investments in Emerging Markets. Financial Analysts Journal (July-August): 76-78.

Finnemore, Martha, and Kathryn Sikkink. (1998) International Norm Dynamics and Political Change. International Organization 52 (4): 887-917.

Glantz, Stanton, Alan Abramowitz, and Michael Burkhart. (1976) Election Outcomes: Whose Money Matters? Journal of Politics 38 (4): 1033-1038.

Golder, Matthew. (2005) Democratic Electoral Systems Around the World, 1946-2000. Electoral Studies 24 (1): 103-121.

Goshen, Zohar, and Gideon Parchomovsky. (2001) On Insider Trading, Markets, and "Negative" Property Rights in Information. Virginia Law Review 87: 1229-1277.

Gourevitch, Peter A., And James Shinn. (2005) Political Power and Corporate Control: the New Global Politics of Corporate Governance. Princeton, NJ: Princeton University Press.

Green, Donald, and Jonathan Krasno. (1988) Salvation for the Spendthrift Incumbent: Reestimating the Effects of Campaign Spending in House Elections. American Journal of Political Science 32: $884-907$.

Grossman, Gene M., and Elhanan Helpman. (1994) Protection for Sale. American Economic Review 84 (4): 833-850.

Grossman, Gene M., and Elhanan Helpman. (1996) Electoral Competition and Special Interest Politics. Review of Economic Studies 63 (2): 265-286. 
Grossman, Gene M., and Elhanan Helpman. (2001) Special Interest Politics. Cambridge, MA and London, UK: MIT Press.

Hansmann, Henry, and Reiner Kraakman. (2001) The End of History for Corporate Law. Georgetown Law Journal 89 (2): 439-468.

Harvey, Campbell. (1993) Portfolio Enhancement with Emerging Markets and Conditioning Information. In Portfolio Investment in Developing Countries, edited by Stijn Claessens and Sudarshan Gooptu. Washington, D.C.: World Bank, 110-144.

Hebb, Tessa, and Dariusz Wójcik. (2005) Global Standards and Emerging Markets: The Institutional Investment Value Chain and CalPERS' Investment Strategy. Environment and Planning A 37 (11): 1955-1974.

Henisz, Witold J. 2008. The Political Constraint Index (POLCON) Dataset. Available at http:// www-management. wharton. upenn. edu/henisz.

Hibbs, Douglass A. (2000) Bread and Peace Voting in US Presidential Elections. Public Choice 104 (1): 149-180.

Jacobson, Gary C. (1978) The Effects of Campaign Spending in Congressional Elections. American Political Science Review 72 (2): 769-783.

Jacobson, Gary. (1980) Money in Congressional Elections. New Haven: Yale University Press.

Jacobson, Gary. (1985) Money and Votes Reconsidered: Congressional Elections, 1972-1982. Public Choice 47 (1): 7-62.

Jacobson, Gary. (1990) The Effects of Campaign Spending in House Elections: New Evidence for Old Arguments. American Journal of Political Science 34: 334-362.

Kamar, Ehud. (2006) Beyond Competition for Incorporations. Georgetown Law Journal 94: 1725.

Khanna, Tarun, Joe Kogan, and Krishna Palepu. (2006) Globalization and Similarities in Corporate Governance: A Cross-Country Analysis. The Review of Economics and Statistics 88 (1): 69-90.

King, Robert G., and Ross Levine. (1993) Finance and Growth: Schumpeter might be Right. Quarterly Journal of Economics 108: 717-738.

La Porta, Rafael, Florencio Lopez-de-Silanes, Andrei Shleifer, and Robert W. Vishny. (1998) Law and Finance. Journal of Political Economy 106 (6): 1113-1155.

la Porta, Rafael, Florencio Lopez-de-Silanes, Andrei Shleifer, and Robert Vishny. (1997) Legal Determinants of External Finance. Journal of Finance 52 (3): 1131-1150.

La Porta, Rafael, Florencio lopez-de-Silanes, Andrei Shleifer, and Robert Vishny. (2000) Investor protection and corporate governance. Journal of Financial Economics 58 (1-2): $3-27$.

Lensink, Robert, Niels Hermes, and Victor Murinde. (2000) Capital Flight and Political Risk. Journal of Money and Finance 19 (1): 73-92.

Levitt, Steven D. (1994) Using Repeat Challengers to Estimate the Effect of Campaign Spending on Election Outcomes in the U.S. House. Journal of Political Economy 102 (4): 777-798.

Manne, Henry. (1966) Insider Trading and the Stock Market. New York: Free Press.

Pagano, Marco, and Paolo F. Volpin. (2001) The Political Economy of Finance. Oxford Review of Economic Policy 17 (4): 502-519.

Pagano, Marco, and Paolo F. Volpin. (2005) The Political Economy of Corporate Governance. American Economic Review 95 (4): 1005-1030.

Perotti, Enrico C., and Paolo F. Volpin. (2004). Lobbying on Entry. EFA 2004 Maastricht Meetings Paper No. 2277. Available at SSRN: http://ssrn.com/abstract=558588.

Perotti, Enrico C., and Paolo F. Volpin. (2007). Politics, Investor Protection and Competition. ECGI - Finance Working Paper No. 162/2007. Available at SSRN: http://ssrn.com/abstract= 957783.

Perotti, Enrico C., and Ernst-Ludwig. von Thadden. (2006) The Political Economy of Corporate Control and Labor Rents. Journal of Political Economy 114 (1): 145-175.

Rajan, Raghuram G., and Luigi Zingales. (2003) The Great Reversals: The Politics of Financial Development in the Twentieth Century. Journal of Financial Economics 69 (1): 5-50.

Roe, Mark J. (2003) Political Determinants of Corporate Governance: Political Context, Corporate Impact. Oxford and New York: Oxford University Press.

Rogowski, Ronald, And Mark A. Kayser. (2002) Majoritarian Electoral Systems and Consumer Power: Price-Level Evidence from the OECD Countries. American Journal of Political Science 46 (3): 526-539.

Scartascini, Carlos G. (2002) Political Institutions and Regulation: An Inquiry on the Impact of Electoral Systems on the Regulation of Entry. Manuscript, available at http://www.gmu.edu/ departments/economics/bcaplan/scar.pdf. 
Schmidbauer, Robert. (2006) On the Fallacy of LLSV Revisited-Further Evidence About Shareholder Protection in Austria and the United Kingdom. Available at SSRN: http://ssrn.com/ abstract $=913968$.

Simmons, Beth, and Zachary Elkins. (2004) The Globalization of Liberalization: Policy Diffusion in the International Political Economy. American Political Science Review 98 (1): 171-189.

Svaleryd, Helena, and Jonas Vlachos. (2005) Financial Markets, The Pattern of Industrial Specialization and Comparative Advantage: Evidence From OECD Countries. European Economic Review 49 (1): 113-144.

Tiberghein, Yves. (2007) Entrepreneurial States: Reforming Corporate Governance in France, Japan and Korea. Ithaca: Cornell University.

Welch, W.P. (1981) Money and Votes: A Simultaneous Equations Model. Public Choice (36): 209-234. 